\title{
SERPINB2 Gene
}

National Cancer Institute

\section{Source}

National Cancer Institute. SERPINB2 Gene. NCI Thesaurus. Code C39653.

This gene plays a role in the regulation of transcription, cell proliferation and cell differentiation. It is also involved in the inhibition of apoptosis. 